\title{
KARA POZBAWIENIA WOLNOŚCI - SYTUACJA KRYZYSOWA W ŻYCIU SKAZANEGO I JEGO RODZINY
}

\begin{abstract}
Streszczenie
Kara pozbawienia wolności to jeden z podstawowych instrumentów oddziaływania na sprawców przestępstw. Jakkolwiek kara ta stanowi naturalna $i$ w petni uzasadniona konsekwencję społecznie nieakceptowanego czynu, nie można pominać faktu, że jej zastosowanie także pociaga za soba negatywne nastepstwa. Co warte podkreślenie, uwięzienie jednego z członków rodziny negatywnie rzutuje nie tylko na funkcjonowanie samego skazanego, ale również całego systemu rodzinnego.

Niniejszy artykut jest próbą ukazania problemów, z jakimi spotykaja się w związu z uwięzieniem osadzony i jego rodzina, ze szczególnym uwzględnieniem sytuacji dzieci osób pozbawionych wolności. Całość tekstu zamykaja wnioski, postulaty dotyczace opisanej problematyki.
\end{abstract}

Słowa kluczowe: więźniowie, kara pozbawienia wolności, kryzys, rodziny więźniów, dzieci więźniów

\section{Wstęp}

Wiek XXI to bez wątpienia okres gwałtownych transformacji i zmian w różnych obszarach życia ludzkiego. Codziennie obserwować możemy rozwój nowoczesnych technologii i postępujący w ślad za nim wzrost znaczenia teleinformatyki. W konsekwencji coraz trudniej wyobrazić sobie życie bez popularnych ,gadżetów”, umożliwiających wirtualny kontakt, bez potrzeby spotkania w rzeczywistym

* Renata Deka - doktorantka na Wydziale Nauk Pedagogicznych Uniwersytetu Mikołaja Kopernika w Toruniu. 
czasie i przestrzeni. Wręcz przeciwnie, w wielu przypadkach wirtualne relacje zaczynają wypierać dotychczasowe, oparte na bliskości, otwartości, zaufaniu. Żyjemy zatem w tzw. „globalnej wiosce”, w której nie ma barier i ograniczeń. Łatwy dostęp do usług i wiedzy powoduje, że najważniejszym dobrem staje się informacja. Jej szybki przepływ wydawał się być nadzieją na lepszą przyszłość, można jednak zauważyć, że staje się odwrotnie i obecnie mamy wręcz do czynienia z przeładowaniem informacyjnym. Nadmiar informacji dostarczanych przez rozmaite media powoduje chaos i niepewność $\mathrm{w}$ dynamicznie zmieniającej się rzeczywistości. Jednocześnie tradycyjne wartości, jak rodzina, miłość, przyjaźń, ustępują miejsca pracy, pieniądzom, karierze, a dotychczasowe sposoby rozwiązywania problemów okazują się niewystarczające. Wszystkie te czynniki stają się źródłem coraz to nowych trudności i kryzysów, z którymi człowiek musi się mierzyć. Pozbawiony odpowiedniego wsparcia, autorytetów podejmuje decyzje, które prowadzić mogą do kolejnych sytuacji kryzysowych. Z takim schematem mamy wielokrotnie do czynienia w przypadku sprawców przestępstw. Osoba nie radząc sobie z problemami, chociażby finansowymi, podejmuje decyzję, która wydaje się być rozwiązaniem jej problemów - popełnia przestępstwo. W następstwie zostaje umieszczona w zakładzie karnym, co stanowi dalszą sytuacje trudną w życiu człowieka. Sytuację, która stać się może źródłem kolejnego kryzysu, kryzysu dotykającego nie tylko skazanego, ale i całej jego rodziny.

Celem artykułu jest ukazanie izolacji penitencjarnej jako sytuacji kryzysowej dotykającej osoby pozbawione wolności oraz ich bliskich, dlatego w kolejnych częściach niniejszego tekstu zostaną omówione konsekwencje izolacji więziennej dla samego skazanego, rodziny osoby pozbawionej wolności oraz dzieci rodziców przebywających w jednostkach penitencjarnych. Istotne wydaje się pochylenie zwłaszcza nad sytuacją dzieci skazanych, które zdają się ponosić największe koszty przymusowej izolacji rodzica/rodziców, a mimo to ich sytuacja rzadko stanowi przedmiot osobnych rozważań i dyskusji. Główną tezę tekstu można by ująć w stwierdzenie: Kara pozbawienia wolności, jakkolwiek słuszna i stanowiąca konsekwencję czynu przestępczego (w wyniku którego krzywdę poniósł inny człowiek), pociąga za sobą rozliczne niepożądane następstwa, które dotykają nie tylko samego sprawcy, ale także wszystkich w jakikolwiek sposób z nim związanych. Pojawia się zatem problem: $W$ jaki sposób przeciwdziałać negatywnym konsekwencjom przymusowej izolacji czy jakie działania podejmować, by te niepożądane skutki redukować?, którego próba rozwiązania zostanie podjęta w toku prowadzonych rozważań. 


\section{Czym jest kryzys?}

Kryzys to pojęcie, które w ostatnim czasie zyskało znaczną popularność i z reguły ma pejoratywny wydźwięk, wskazując na pewien aspekt zagrożenia. Środki masowego przekazu informują nas o kryzysie demograficznym, kryzysie politycznym, kryzysie migracyjnym, kryzysie finansowym. Z mniejszą bądź większą częstotliwością kryzysy występują też w życiu każdego człowieka. Czym zatem jest kryzys? Samo słowo pochodzi z języka greckiego i wywodzi się od czasownika krinein, co oznacza rozdzielać, odsiewać, decydować, rozstrzygać, natomiast pochodzący od czasownika rzeczownik krisis znaczy wybór, rozstrzygnięcie. Etymologia słowa nie wskazuje na jego pejoratywny wydźwięk, dając raczej do zrozumienia, że jest to pewnego rodzaju moment przełomowy, zmuszający do podjęcia określonych decyzji. Według Z. Płużek kryzys to natomiast „reakcja człowieka zdrowego na trudną sytuację, w której nie można wykorzystać swoich umiejętności rozwiązywania problemów, gdyż stały się już niewystarczające. Nie ma gotowych sposobów radzenia sobie i stąd następuje faza poszukiwania rozwiązania"”. G.W. Allport twierdzi z kolei, że kryzys „to sytuacja emocjonalnego i umysłowego stresu, wymagająca zmian perspektyw w ciągu krótkiego czasu. Te zmiany perspektyw wywołują często zmiany struktury osobowości. Zmiany te mogą być progresywne, albo mogą być regresywne"2. Kryzys to zatem szczególnie trudna sytuacja w życiu jednostki, która zakłóca jej normalny sposób funkcjonowania, co wymusza konieczność poszukiwania nowych sposobów działania, przy czym działania te mogą mieć charakter konstruktywny bądź destruktywny. Należy mieć jednocześnie świadomość, że kryzys nie pojawia się z dnia na dzień i równie szybko nie znika, a w jego przebiegu możemy wyróżnić pewne następujące po sobie fazy. Twórca jednej z teorii kryzysu - G. Caplan wskazuje na następujące fazy kryzysu:

- faza konfrontacji z wydarzeniem wywołującym kryzys - osoba doświadczająca kryzysu uświadamia sobie nieadekwatność znanych rozwiązań i sposobów działania, w efekcie czego pojawiają się u niej lęk, niepokój, napięcie;

- faza pojawienia się przekonania, że nie jest się w stanie poradzić sobie z zaistniałą trudnością - osoba traci nadzieję na rozwiązanie problemu, czuje się bezsilna i pokonana, co w rezultacie może prowadzić do spadku poczucia własnej wartości;

1 Z. Płużek, Psychologia pastoralna, Inst. Teolog. Księży Misjonarzy, Kraków 1991, S. 87

2 G.W. Allport, Osobowość i religia, PAX, Warszawa 1988, s. 64. 
- faza mobilizacji - etap, na którym możliwe są dwa rozwiązania: albo osoba pokona kryzys i odzyska utraconą równowagę, albo poprzez zaprzeczanie pozornie poradzi sobie z sytuacją, co może doprowadzić do przejścia kryzysu w stan chroniczny. Jeżeli żaden z tych wariantów nie będzie miał miejsca dochodzi do fazy czwartej;

- faza dekompensacji - to następstwo niemożliwego do wytrzymania napięcia. U osoby ma miejsce zniekształcenie procesów poznawczych, czuje się wewnętrznie rozbita i wycofuje się z kontaktów. Na tym etapie mogą się pojawić niepożądane zachowania o charakterze destrukcyjnym, jak np. autoagresja, próby samobójcze, uzależnienia ${ }^{3}$.

Kryzys to przejściowe zaburzenie równowagi, dotychczasowego sposobu funkcjonowania, dlatego też budzi u człowieka lęk, obawy, poczucie frustracji i zagrożenia. Trudno jednak z góry przewidzieć, jaki będzie efekt wystąpienia kryzysu. Zdarza się, że przyczynia się on do wykształcenia czegoś nowego, pozwala zapoczątkować zmiany i w rezultacie daje pozytywne efekty. Pozytywne rozwiązanie zaistniałych trudności może prowadzić do umocnienia własnej osobowości i podniesienia poczucia wartości własnego ja. Wskazywał na to w swojej koncepcji zwłaszcza E. Erikson, podkreślając, że pozytywne rozwiązanie zaistniałych trudności umożliwia przejście na wyższy poziom rozwoju, pozwala na dokonanie zmiany w spojrzeniu na siebie, innych i świat ${ }^{4}$, także efekty kryzysu jesteśmy tak naprawdę w stanie ocenić dopiero po jego zaistnieniu, a czasami wręcz ustąpieniu.

\section{Izolacja więzienna jako przykład sytuacji kryzysowej}

Kara bezwzględnego pozbawienia wolności oznacza w praktyce umieszczenie w warunkach izolacji. Umieszczenie to odbywa się na mocy decyzji sądu, czyli innych ludzi, a więc stanowi formę przymusu, a nie dobrowolnego wyboru. $Z$ tego chociażby powodu można izolację więzienną zaliczyć do grona sytuacji trudnych, kryzysowych ${ }^{5}$. Więzienia to jednocześnie miejsca, które z reguły dostarczają zbyt mało stymulujących do aktywności bodźców. Architektura (która ma uniemożliwić kontakt ze światem zewnętrznym oraz między osadzonymi), ubóstwo barw ${ }^{6}$

\footnotetext{
3 Por. G. Caplan, Principles of preventive psychiatry, Basic Book, New York 1964.

4 Por. R.J, Gerrig, P.G. Zimbardo, Psychologia i życie, PWN, Warszawa 2006.

5 http://agb.waw.pl/cms/index.php/zakad-karny/placowki/33-izolacja-wizienna [dostęp: 20.08.2017]

6 Wiele miejsca znaczeniu barw w środowisku więziennym dla funkcjonowania osadzonych poświęca J. Sikora. Zob. J. Sikora, Znaczenie barw w życiu człowieka $i$ w warunkach izolacji więziennej, „Przegląd penitencjarny i kryminologiczny” 1971, nr 1.
} 
(zdecydowana przewaga kolorów w odcieniach brudnej cegły i szarości), monotonia przestrzeni oraz nuda i rutyna dnia codziennego zdecydowanie negatywnie rzutują na emocjonalne funkcjonowanie osadzonych. Co więcej, badania przeprowadzone przez Wawrzyniak i Chmielewską ${ }^{7}$ pokazują, że więźniowie mają podwyższony poziom aleksytymii ${ }^{8}$.

Izolacja więzienia zaliczana jest do grona sytuacji trudnych również ze względu na aspekt funkcjonalny tejże sytuacji. Pozbawienie wolności skutkuje ograniczeniem swobody działania i możliwości utrzymywania kontaktów z bliskimi. Skazany pozbawiony jest decyzyjności w większości spraw, dostosować się musi do zakładowych reguł i regulaminów, a każde jego zachowanie podlega kontroli i nadzorowi. Wielokrotnie towarzyszą mu również poczucie utraty bezpieczeństwa bądź obawy przed jego utratą. Paradoksalnie, w warunkach izolacji nie ma miejsca i możliwości, by „wyizolować się” od współosadzonych, a konieczność nieustannego przebywania w ich towarzystwie staje się źródłem napięć i nieporozumień. Co więcej, osadzenie wiąże się z pozbawieniem udogodnień mieszkaniowych (np. zła wentylacja, hałas, zmiany celi, wilgoć, przeludnienie) oraz usługowych, co staje się niejednokrotnie przyczyną niezadowolenia i skarg osadzonych ${ }^{9}$. Pobyt w więzieniu wiąże się ponadto $\mathrm{z}$ koniecznością przebywania $\mathrm{w}$ jednopłciowej społeczności i oznacza pozbawienie możliwości utrzymywania kontaktów heteroseksualnych, co może negatywnie rzutować na obraz samego siebie i prowadzić do zaburzeń w sferze seksualnej (zwłaszcza u młodych osadzonych) ${ }^{10}$.

Kolejny obszar trudności związanych z izolacją więzienną dotyczy aspektu przestrzenno-czasowego. W odniesieniu do przestrzeni podnoszona jest przede wszystkim kwestia wspomnianych już warunków mieszkaniowych oraz nadal występujące w wielu zakładach karnych problemy z przeludnieniem, które mogą powodować złe samopoczucie, zmiany nastroju, napięcia wewnętrzne czy zachowania

\footnotetext{
7 M. Wawrzyniak, A. Chmielewska, Uwięzienie a syndrom aleksytymii, „Psychologia Jakości Życia” 2002, nr 1-2, s. 115-127.

8 Aleksytymia definiowana jest jako nieumiejętność do rozpoznawania własnych stanów emocjonalnych i brak słów do ich opisu, ubóstwo wyobraźni i fantazji oraz nieumiejętność różnicowania między przeżywaną emocją a jej wskaźnikiem fizjologicznym - M. Wawrzyniak, H. Chmielewska-Hampel, Izolacja więzienna jako sytuacja trudna a aleksytymia, „Psychologia jakości życia” 2009, tom 8, nr 2, s. 125.

9 Por. M. Lewandowski, Pęknięcie ziemi, Czytelnik, Warszawa 1975.

10 Por. J.S. Giza, W. Morasiewic, Homoseksualizm w środowisku więźniów młodocianych, „Przegląd Penitencjarny” 1968, nr 4.
} 
agresywne bądź autoagresywne ${ }^{11}$. Z kolei w odniesieniu do czasu, w warunkach izolacji największy problem z nim związany to jego nadmiar. Osadzeni zmagają się z rutyną dnia codziennego, a ograniczone możliwości decyzyjne powodują, że nie mają zbyt wielu okazji do tego, by zagospodarować go w interesujący sposób. Pojawia się zatem problem, co zrobić z czasem, by upływał w miarę szybko i niepostrzeżenie, a nie był czymś monotonnym i wręcz nierealnym ${ }^{12}$.

Ostatni z obszarów trudności dotyczy aspektu społecznego środowiska więziennego. W więzieniu nie liczy się tylko, jak spędza się czas, ale przede wszystkim z kim. W odniesieniu do tego aspektu można wskazać na pewne grupy problemów. Pierwsza z nich to sposób funkcjonowania całej społeczności więziennej. Mówiąc o społeczności należy mieć na uwadze nie tylko społeczność osadzonych, ale i funkcjonariuszy Służby Więziennej, liczą się zatem nie tylko relacje między więźniami czy między personelem, ale też pomiędzy obiema grupami ${ }^{13}$. Inny obszar dotyczy mechanizmów powstawania i funkcjonowania grup nieformalnych oraz tzw. podkultury więziennej. Należy mieć tutaj na uwadze, jakie zachowania grupy te akceptują i preferują, jaki system ról kreują, jakie zwyczaje/tradycje tworzą i w jaki sposób je przekazują ${ }^{14}$.

Wszystkie opisane powyżej trudności pokazują, że izolacja więzienna w znacznym stopniu utrudnia realizację potrzeb osób w niej przebywających, zarówno o charakterze fizycznym, jak i psychicznym, a ograniczenie to prowadzi z kolei do deprywacji, frustracji, zagrożeń oraz sytuacji konfliktowych ${ }^{15}$.

\section{Negatywne konsekwencje pobytu w warunkach izolacji penitencjarnej}

Kara pozbawienia wolności, jak już zauważono we wstępie, stanowi naturalną konsekwencję zachowania przestępczego. Pomimo iż jest zasłużoną reakcją na społecznie nieakceptowane zachowanie, a w związku z tym ma prowadzić do poprawy sprawcy, nie można pominąć faktu, iż wielokrotnie prowadzi do wystąpienia u osób osadzonych niekorzystnych zmian, ulegających intensyfikacji wraz

11 Por. V.C Cox., P.B. Paulus, G. McCain, Prison crowding research, „American Psychologist" 1984, nr 39.

12 eWKratke - blog kobiet osadzonych w Areszcie śledczym Warszawa-Grochów, http://ewkratke.blog.pl/2014/09/01/tryptyk-jak-plynie-czas-w-wiezieniu [dostęp: 25.07.2017]

13 Por. M. Kosewski Agresywni przestepcy, Wiedza Powszechna, Warszawa 1977.

14 Por. S. Przybyliński, Podkultura więzienna - wielowymiarowość rzeczywistości penitencjarnej, Oficyna Wydawnicza Impuls, Kraków 2012.

15 R. Poklek, Instytucjonalne i psychospołeczne aspekty więzienia, Centralny Ośrodek Szkolenia Służby Więziennej, Kalisz 2010, s. 52-55. 
z wydłużaniem się jej okresu ${ }^{16}$. Należy też zauważyć, że negatywne konsekwencje pobytu w zakładzie karnym mogą wystąpić we wszystkich sferach funkcjonowania jednostki. Do najpoważniejszych należy zaliczyć zmiany w zakresie tożsamości (wykształcanie tożsamości nieautonomicznej, lustrzanej czy opozycyjnej) ${ }^{17}$. Poza zmianami w zakresie własnej tożsamości, osadzeni doświadczają różnorakich chorób fizycznych bądź psychosomatycznych, będących następstwem dotychczasowego trybu życia ${ }^{18}$. U więźniów wielokrotnie ma miejsce proces depersonalizacji, czyli subiektywnego poczucia wewnętrznej zmiany, przeżywanej jako poczucie obcości czy nawet nierealności, pojawiającego się na skutek silnego stresu lub też długotrwałych sytuacji trudnych, co finalnie prowadzi do zmiany w osobowości więźniów, głównie w zakresie obrazu samego siebie. Depersonalizacja może stanowić następstwo niemożliwości realizowania celów i planów na przyszłość, trudności w życiu rodzinnym czy też deprywacji potrzeb emocjonalnych, jak chociażby potrzeby miłości i bliskości drugiej osoby ${ }^{19}$. Deprywację potrzeb, nie tylko tych emocjonalnych (może dotyczyć też potrzeb żywieniowych, seksualnych itp.), zaobserwować można u wszystkich osadzonych, a jej konsekwencją jest nasilanie negatywnych postaw skazanych wobec „wolnej” części społeczeństwa. Problem powszechnie występujący w zakładach karnych stanowi równocześnie wzajemna demoralizacja więźniów. Izolacja od społeczeństwa przyczynia się do zaniku poczucia odpowiedzialności osadzonych oraz poszanowania powszechnie obowiązujących norm i wartości, a co za tym idzie ułatwia utożsamianie z postawami i wartościami grupy przestępczej. Jednocześnie następuje ograniczenie liczby pozytywnych uczuć i realizowanych ról życiowych, co niekorzystnie wpływa na jakość więzi emocjonalnych skazanych, dodatkowo zmniejszając ich motywację do pracy nad sobą ${ }^{20}$. Konsekwencją deprywacji potrzeb mogą być również agresja i autoagresja, przyjmujące postać samookaleczeń lub ataków na współwięźniów, w tym także agresji seksualnej.

16 M. Ciosek, Psychologia sądowa i penitencjarna, PWN, Warszawa 2001, s.216.

17 Por. R. Deka, Zaangażowanie więźniów w praktyki religijne jako jedna z form zapobiegania negatywnym konsekwencjom izolacji więziennej, [w:] Badania i Rozwój Młodych Naukowców w Polsce. Nauki humanistyczne i społeczne, cz. III, red. J. Nyćkowiak, J. Leśny, Wyd. Młodzi Naukowcy, Poznań 2017.

18 A. Jaworska, Leksykon resocjalizacji, Oficyna Wydawnicza Impuls, Kraków 2012.

19 W. Chmielewska, Psychologiczne aspekty izolacji, w: Zagadnienia penitencjarne. Skrypt dla stuchaczy szkoły podoficerskiej $S W$, red. H. Chmielewska i in., Kalisz 2004.

20 Por. R. Poklek, dz. cyt. 
Jak zaznaczono w powyższej części, warunki stwarzane przez zakłady karne pod każdym względem znacznie odbiegają od „wolnościowych standardów”, dlatego też niezbędne jest wykształcenie technik adaptacyjnych, które pozwolą na „odnalezienie się” w nowej rzeczywistości. Do technik tych zalicza się: wycofanie się, bunt, zadomowienie, konwersję i zimną kalkulację ${ }^{21}$. Pobyt w zakładzie karnym wielokrotnie prowadzi także do wyuczonej bezradności i poniekąd stopniowego uzależniania się od decyzji administracji, która odpowiada za zapewnienia skazanym miejsca do spania, przygotowuje posiłki, organizuje zajęcia i zatrudnienie. W przypadku osadzonych postawa wyuczonej bezradności stanowi konsekwencję tego, iż w więzieniach brak jest miejsca na samodzielność czy planowanie, co poniekąd prowadzi do zaniku zdolności samodzielnego działania i myślenia.

Poważnym problemem dotykającym osoby pozbawione wolności są procesy standaryzacji i degradacji. Standaryzacja to efekt zawartych w regulaminie więziennym zasad postępowania z osadzonymi, wskazujących dokładny rodzaj ubioru, ilość i rodzaj posiadanego mienia prywatnego oraz sposoby realizowania podstawowych potrzeb. Proces ten zaprzecza ogólnoludzkiej potrzebie bycia niepowtarzalnym i indywidualnym, w efekcie wywołując uczucie zagrożenia i niepokoju, czy nawet zachowania mające na celu zwrócenie uwagi na swoją osobę. $Z$ kolei proces degradacji powoduje, iż skazany staje się często obiektem manipulacji, zarówno ze strony administracji zakładowej, jak i silniejszych więźniów, a co za tym idzie znajduje się w sytuacjach upokarzających czy umniejszających jego godności²2.

Problemem, z jakim przychodzi zmierzyć się osobom opuszczającym zakłady karne jest stygmatyzacja, czyli kształtowanie negatywnej tożsamości społecznej. Proces ten rozpoczyna się już na etapie dochodzenia i aresztu, a skazujący wyrok sądu potwierdza jedynie przypuszczenia, że jednostka popełniła przestępstwo. Kolejny etap stygmatyzacji przypada na czas pobytu w zakładzie karnym. Osadzonym przypomina się, że utracili status normalnego obywatela, postrzega się ich przez pryzmat popełnionego czynu i nawet po opuszczeniu więzienia traktuje jak „dewiantów”. Co więcej, etykieta cechuje się trwałością, co oznacza, że raz nadana zwykle zostaje na zawsze i niezwykle trudno jest się od niej uwolnić23. Na skutek nadanej etykiety u skazanego może pojawić się poczucie jej trafności, utożsamianie się z nią i angażowanie się w działania, które będą ją potwierdzać. Stygmatyzacja zwykle prowadzi również do wykluczenia społecznego byłych

21 Por. E. Goffman, Charakterystyka instytucji totalnych, w: Elementy teorii socjologicznych. Materiały do dziejów współczesnej socjologii Zachodniej, red. W. Derczyński, A. Jasińska-Kania, J. Szacki, 1975.

22 R. Poklek, dz. cyt., s. 42-45.

23 J. Terelak, Człowiek i stres, Wyd. UKSW, Warszawa 2007. 
więźniów. Przez część społeczeństwa są oni postrzegani stereotypowo, jako osoby niegodne zaufania i niezdolne do okazywania uczuć wyższych, a co za tym idzie angażowania się w prawidłowo funkcjonujące związki międzyludzkie.

Izolacja więzienna rzutuje w sposób negatywny na relacje rodzinne osób pozbawionych wolności. W przypadku gdy czyn dokonany przez osadzonego przyczynił się do szkody systemu rodzinnego i zachwiał jego funkcjonowaniem bliscy z reguły starają się unikać wzajemnych kontaktów i nie wykazują zainteresowania losami skazanego. Jest to ogromny problem, ponieważ rodzina zwykle postrzegana jest jako swoisty „sojusznik” procesu resocjalizacji, element zapewniający więźniom kontakt z szerszym środowiskiem i światem społecznym, czynnik rzutujący na ich samoocenę, poczucie bycia ważnym i potrzebnym ${ }^{24}$. Jednocześnie należy zauważyć, że przymusowa izolacja w wielu przypadkach skłania osoby pozbawione wolności do przemyśleń, jak ważna jest rodzina w ich życiu i jak wiele tracąc spędzając czas w zakładzie karnym. Potwierdzenia dla powyższej tezy dostarczają badania T. Sakowicza, z których to wynika, że dla większości badanych osadzonych dobro rodziny stanowi podstawową wartość, a akceptacja i otwartość ze strony najbliższych jest jednym z ich podstawowych oczekiwań ${ }^{25}$.

Wyżej wymienione problemy nie zamykają katalogu trudności, z jakimi przychodzi się zmierzyć osobom odbywającym kary pozbawienia wolności. Uzależnione są one od indywidualnej sytuacji osadzonego i wsparcia, jakie otrzymuje. Nie da się jednak zaprzeczyć, że rzutują na jakość powrotu do społeczeństwa po odbyciu kary i to, czy osoba będzie w stanie funkcjonować w zgodzie z obowiązującymi normami - zarówno prawnymi, jak i społecznymi.

\section{Rodzina wobec izolacji jednego $\mathrm{z}$ jej czlonków}

Rodzina pełni niezwykle istotną rolę w życiu każdego człowieka, szczególnie zaś człowieka pozbawionego wolności. W przypadku skazanych jest ona zazwyczaj najważniejszym, jeżeli nie jedynym źródłem wsparcia i łączności ze światem zewnętrznym. Bliscy zajmują się sprawami osadzonych, także tymi związanymi z przestępstwem, przez co często spotykają się z potępieniem i wykluczeniem społecznym. To oni zapewniają wsparcie i starają się zaspokoić potrzeby emocjonalne skazanych, a kontakt z nimi korzystnie wpływa na samoocenę osób pozbawionych wolności, kształtuje pozytywny obraz samego siebie, daje poczucie, że są nadal

24 E. Pindel, Podtrzymywanie więzi rodzinnych $w$ warunkach izolacji, „Probacja” 2011, nr 1 , s. $92-99$.

25 T. Sakowicz, Dysfunkcjonalność rodziny a resocjalizacja, Oficyna Wydawnicza Impuls, Kraków 2006, s. 78 - 82. 
potrzebni i mają dokąd wracać26. Właściwie funkcjonująca rodzina jest nie tylko źródłem wsparcia, ale może też motywować do pracy nad sobą i pokonywania sytuacji kryzysowych, a tym samym ma wpływ na sukces procesu resocjalizacji i readaptacji ${ }^{27}$. Warunkiem niezbędnym, by rodzina mogła trwać i rozwijać się jest jednak posiadanie więzi, która stanowi niejako podstawę jej funkcjonowania, co $\mathrm{w}$ warunkach izolacji jest trudne i wynika w dużej mierze z braku stałego kontaktu między członkami rodziny oraz niewłaściwych stylów komunikacji. Zważywszy na ten fakt, wydaje się konieczne posiadanie szerokiej wiedzy na temat sytuacji rodzin osób pozbawionych wolności, z uwzględnieniem długości kary jako czynnika tę sytuację różnicującego. Tymczasem w Polsce nadal brakuje pogłębionych badań z tego zakresu, co potwierdza gruntowny przegląd dostępnej literatury, przeprowadzony przez R. Szczepanik i K. Miszewskiego ${ }^{28}$. W dyskusji naukowej rodzina zwykle stanowi swoiste tło dla rozważań o uwarunkowaniach procesu resocjalizacji, o sytuacji skazanych, nie podejmuje się jednak trudu dokonania wnikliwej diagnozy, jaka jest sytuacja rodzin tychże osób, jak uwięzienie jednego z członków wpłynęło na jej funkcjonowanie, jak bliscy radzą sobie z sytuacją, w jakiej się znaleźli. Wydaje się, że jest to olbrzymi błąd i obszar, który należy zgłębić, mając na uwadze, że rodzina to system, w którym poszczególne elementy oddziałują na siebie i wzajemnie się modyfikują. Tak też dzieje się w sytuacji uwięzienia jednego z członków rodziny, które to wywiera określone konsekwencje zarówno na poszczególnych członkach rodziny, jak i rodzinie jako całości. Konsekwencje te zostaną omówione w dalszej części artykułu, należy mieć jednak na uwadze, iż są one znacząco różne w zależności od płci osoby, która w izolacji przebywa, dlatego też zostaną one omówione w odniesieniu do uwięzienia mężczyzny. Co więcej, brana jest pod uwagę sytuacja, gdy skazany nie dopuścił się przestępstwa przeciwko rodzinie, w przeciwnym bowiem razie bliscy postrzegają zwykle uwięzienie jako szansę na uwolnienie się od ,rodzinnego kata” i zrywają z nim wszelkie relacje.

26 A. Rzepliński, Rodziny więźniów dtugoterminowych, Ossolineum, Wrocław 1981, s. $13-16$.

27 J.C. Cochra, D.P. Mears, Social isolation and inmate behavior: A conceptual framework for theorizing prison visitation and guiding and assessing Research, „Journal of Criminal Justice"2013, nr 41, s.252-261.

28 R. Szczepanik, K. Miszewski, Wpływ dtugoterminowego uwięzienia na rodziny więźniów - stan wiedzy i zaniedbane kierunki badań, „Profilaktyka Społeczna i Resocjalizacja” 2016, nr 30, s.53-95. 
W takich sytuacjach kara pozbawienia wolności nie staje się źródłem kryzysu, a raczej szansą dla rodzin osób przebywających w zakładach karnych ${ }^{29}$.

Jedną z podstawowych konsekwencji pobytu skazanego w zakładzie karnym jest pogorszenie sytuacji materialnej rodziny, która częstokroć już przed osadzeniem nie należała do najlepszych. Nawet jeżeli przed uwięzieniem skazani nie podejmowali stałego zatrudnienia lub wynagrodzenie, jakie za nie otrzymywali nie wystarczało na zaspokojenie podstawowych potrzeb rodziny, utrata takiego źródła dochodu silnie rzutuje na rodzinny budżet. W konsekwencji rodziny wielokrotnie są zmuszone do korzystania z pomocy społecznej bądź też rodzic pozostały na wolności musi podjąć dodatkowe zatrudnienie w celu zapewnienia bytu rodzinie. Nierzadkie są też sytuacje, gdy to dzieci przejmują na siebie część ciężaru utrzymania domu i podejmują się rozlicznych prac dodatkowych. Jeżeli natomiast nie idą do pracy muszą opiekować się młodszym rodzeństwem, a ponadto spoczywa na nich znacznie więcej obowiązków domowych. Skazujący wyrok sądu nie tylko pozbawia rodzinę jednego ze źródeł dochodu, ale też nastręcza jej dodatkowych wydatków związanych chociażby z koniecznością pokrycia kosztów sądowych, opłacenia adwokata czy wreszcie pokrycia kosztów przejazdu na widzenia do zakładu karnego ${ }^{30}$.

Istotnym problemem, z jakim spotykają się rodziny osób pozbawionych wolności jest stygmatyzacja społeczna. Jak już zostało to zasygnalizowane, rozpoczyna się ona zwykle na etapie postępowania przygotowawczego i aresztu, kiedy pojawia się podejrzenie, że członek rodziny należy do grupy przestępczej bądź dopuścił się czynu niezgodnego z prawem. W efekcie rodzina, która do tej pory nie różniła się niczym od innych, zaczyna być postrzegana przez pryzmat czynu, który popełnił jeden z jej członków. Stosunek sąsiadów i lokalnej społeczności względem niej ulega pogorszeniu, a jej obecność jest wielokrotnie tolerowana z konieczności. Bliscy osadzonego muszą się też przygotować na komentarze typu „żona złodzieja”, „matka zabójcy”31. Podobnie jak byli więźniowie, tak i ich rodziny mają problem z uwolnieniem się od nadanej etykiety, co podkreśla A. Siemaszko: „Powrót byłego

29 P. Gorzelak, Wplyw rodziny na sposób adaptacji młodocianych więźniów $w$ areszcie śledczym na podstawie spotkań organizowanych przez administracje AŚ z rodzinami, w: Młodociani więźniowie. Problemy współczesnej rzeczywistości penitencjarnej, red. L. Lubicki, Wydawnictwo ZK, Włocławek 2001, s.3.

30 A. Barczykowska, Sytuacja życiowa rodzin osób pozbawionych wolności, w: Rodzina i praca z perspektywy wyzwań i zagrożeń, red. L. Golińska, B. Dudek, Wydawnictwo Uniwersytetu Łódzkiego, Łódź 2008, s.348-349.

31 E. Żwyucka-Kozłowska, Naznaczeni, odtraceni, wykluczeni... Kilka uwag o społecznej sytuacji osób opuszczających zakłady karne, w: Meandry wykluczenia społecznego, red. J. Nowak, Wyższa Szkoła Pedagogiczna TWP, Warszawa 2008, s.122. 
więźnia [...] do poprzedniego środowiska odbywa się z reguły bez rozgłosu, najczęściej wręcz wstydliwie i skrycie. Brak jednoznacznego potwierdzenia, że dewiant nie pełni już poprzedniej roli, sprawia, że otoczenie z trudem postrzega go zgodnie z rolą społeczną jaką pełnił w okresie poprzedzającym wciągnięcie go w tryby machiny kontroli społecznej. Społeczeństwo jest raczej skłonne do traktowania takiej osoby zgodnie z jej ostatnią rolą społeczną, to jest właśnie z rolą dewianta" ${ }^{32}$.

Charakter względnie trwały, wymagający wiele pracy, by się z nimi uporać mają także inne doświadczane przez rodziny więźniów problemy. Zmiany w funkcjonowaniu rodziny po powrocie skazanego, zatracenie jego roli jako osoby dominującej bądź zajmującej wysoką pozycję, podważanie autorytetu i roli ojca/partnera, tworzenie się ukrytych konfliktów w zakresie kontaktów małżeńskich oraz pełnienia ról rodzinnych to tylko niektóre z nich. Powrót członka rodziny po odbyciu kary pozbawienia wolności rodzi wielokrotnie pytania: „Jaki on teraz będzie?”, „Jak będzie wyglądało nasze „nowe” wspólne życie?”, a niejednokrotnie wymaga całkowitego przeorganizowania dotychczasowego życia tejże rodziny i w wielu przypadkach oznacza wręcz potrzebę wzajemnego poznania się jej członków od nowa. Nie sprzyjają temu też problemy finansowe, z jakimi borykają się rodziny, a które nie znikają z chwilą powrotu więźnia. Ich pokonanie wymaga dodatkowej pracy, wiąże się bowiem z koniecznością udowodnienia pracodawcom, zwykle nieprzychylnie i nieufnie nastawionym wobec byłych skazanych, że warto im (osadzonym) dać zatrudnienie ${ }^{33}$.

Innym elementem, na który należy zwrócić uwagę $\mathrm{w}$ odniesieniu do rodzin osób pozbawionych wolności, są dysfunkcje czy patologie występujące w tychże rodzinach, wielokrotnie przyczyniające się do podejmowania zachowań przestępczych. Niekorzystna sytuacja materialna rodziny rzadko stanowi jedyną przyczynę przestępstwa. Wielokrotnie w środowiskach rodzinnych (zarówno rodzin generacyjnych, jak i prokreacyjnych) obecne są uzależnienia, brak spójnego systemu norm i zasad czy wyznawanych wartości, jak chociażby poszanowania dla prawa. Innym problemem jest brak wzorców do naśladowania czy prezentowana przez najbliższych negatywna postawa wobec pracy i nauki, rzutująca w przyszłości na zachowania dorosłych/dorastających członków tychże rodzin ${ }^{34}$.

32 A. Siemaszko, Granice tolerancji, PWN, Warszawa 1993, s.295-296.

33 J. Mazur, Wpływ kontaktu z rodzina na funkcjonowanie osadzonego w warunkach izolacji. Realizacja funkcji rodzinnych-próba opisu, w: Osobowość przestępcy a proces resocjalizacji, red. J. Świtka, M. Kuć, I. Niewiadomska (red.), Wydawnictwo KUL, Lublin 2004, s.195-196.

34 T. Sakowicz, dz. cyt., s. 30-31, 78. 


\section{Uwięzienie rodzica a sytuacja dziecka}

„Niewidzialne” ofiary systemu sprawiedliwości... tak mówi się o dzieciach osób pozbawionych wolności. Skąd takie określenie? Przyczyna wydaje się być prosta - dzieci te nie popełniły żadnego przestępstwa, a mimo to też odbywają karę, w pewien sposób „odsiadują swój własny wyrok”. O powadze problemu świadczy jego skala - co roku w państwach członkowskich Rady Europejskiej przynajmniej jednego rodzica w zakładzie karnym ma około 2,1 mln dzieci, w Unii Europejskiej około $1 \mathrm{mln}$, natomiast w Polsce problem ten dosięga ponad 47 tys. dzieci ${ }^{35}$. Każde z tych dzieci musi samodzielnie poradzić sobie z uwięzieniem rodzica, a jego konsekwencje dla rozwoju i funkcjonowania są różne. Zasadniczo podzielić je można na krótkoterminowe i długoterminowe. Wśród konsekwencji krótkoterminowych wyróżnia się: poczucie wstydu, osłabienie relacji z rodzicem przebywającym w zakładzie karnym, stygmat społeczny, zmiany w strukturze rodziny (spowodowane np. rozwodem małżonków), pogorszenie zachowania, spadek poczucia własnej wartości czy obniżenie aspiracji szkolnych uczniów ${ }^{36}$. Do grupy konsekwencji długoterminowych zaliczyć można z kolei: podważanie autorytetu rodzicielskiego skazanego, nieumiejętność konstruktywnego radzenia sobie z problemami czy własnymi emocjami bądź też wykształcenie negatywnego stosunku do prawa i przestrzegania jego zasad (tzw. transmisja pokoleniowa) ${ }^{37}$. Rodzice stanowią dla dzieci wzór do naśladowania, dlatego internalizują one reprezentowane przez nich wartości. I tak w sytuacji, gdy brak jest pozytywnych wzmocnień, rodzic-przestępca podświadomie staje się wzorem, z którego należy brać przykład, co pokazuje K. Dymek-Balcerek: ,proces ciągłego i stałego oddziaływania rodziny oraz brak wzmocnień - w postaci wartości i zasad pozytywnych - powoduje szybką internalizację jedynych znanych norm" ${ }^{\text {"38 }}$. Nawet jeżeli z wiekiem dzieci zaczynają dostrzegać, że zachowanie rodzica jest sprzeczne z obowiązującym prawem, nie negują i nie odrzucają go. Obserwując, jak znaczące i atrakcyjne są uzyskiwane dzięki niemu korzyści, w dalszym ciągu je usprawiedliwiają i akceptują, a niektóre odczuwają nawet dumę z postępowania rodzica. W przyszłości wiele z nich kon-

35 http://fakty.interia.pl/tylko-u-nas/news-winy-rodzicow-nie-pietnuja-dzieci,nId, 2211573 [dostęp: 23.07.2017]

36 J. Hagan, The Next generation: Children of prisoners, „Journal of the Oklahoma Criminal Justice Research Consortium" 1996, nr 3, s. 2-3.

37 J. Travis, E.C. McBrige, A.L. Salomon, Familie left behind: The hiddencosts of incarceration and reentry, Washington, 2003, s.2.

38 K. Dymek-Balcerek, Dziecko w obliczu patologii społecznej dnia codziennego-rzeczywistość lat 90-tych, Wydawnictwo Politechniki Radomskiej, Radom 1999, s. 105. 
tynuuje pewnego rodzaju „rodzinną tradycję” wchodzenia w konflikt z prawem, nie widząc nic złego w popełnianiu przestępstw (,,bo przecież tata czy dziadek też to robili”) bądź też nie wyobrażając sobie innego sposobu funkcjonowania ${ }^{39}$. Jest to oczywiście tylko jeden z możliwych wariantów, bowiem znaczna część dzieci dostrzega niewłaściwość zachowania rodzica i zaczyna się od niego odcinać. Dzieci te nie godzą się na niezgodne z prawem postępowanie i nie są w stanie uporać się $\mathrm{z}$ pobytem ojca $\mathrm{w}$ zakładzie karnym. Czują wstyd, zakłopotanie i w miarę możliwości starają się unikać rozmów o rodzicach. Jeżeli już do nich dojdzie, nie chcą przyznać, że ich ojciec przebywa w więzieniu, a zamiast tego wysyłają komunikaty „mój tata wyjechał” czy nawet ,ja nie mam taty”"40.

Izolacja więzienna, jak już zostało to zasygnalizowane, może przyczyniać się do podważania autorytetu rodzica, który w niej przebywa. Wsparcie ze strony najbliższych stanowi jeden z komponentów kształtowania się tożsamości dziecka, dlatego ma znaczenie w całym okresie rozwoju. Szczególnie istotne zdaje się być jednak w okresie adolescencji, który jest pełen różnorodnych zmian i kiedy to następuje zmiana relacji rodzic - dziecko. Jeżeli na tym etapie rodzic nie zapewnia dziecku poczucia bezpieczeństwa poprzez udzielanie wsparcia, przy jednoczesnym sprawowaniu kontroli i nadzoru nad jego zachowaniem, dorastający człowiek zaczyna poszukiwać akceptacji u innych osób, w innych grupach społecznych (z reguły wybór pada na grupę rówieśniczą). Przynależność do grup czy subkultur młodzieżowych oznacza jednak konieczność angażowania się w zachowania prezentowane i akceptowane przez pozostałych uczestników, nawet jeżeli mają one ryzykowny czy antyspołeczny charakter. U dorastających dzieci mogą zatem pojawić się zachowania szkodliwe, takie jak: szybkie opuszczenie domu rodzinnego, tworzenie krótkotrwałych, raniących związków emocjonalnych, rezygnacja ze szkoły, brak wyuczonego zawodu, a w konsekwencji brak pracy i wreszcie popełnianie prze$\mathrm{stęp}_{\mathrm{st}} \mathrm{w}^{41}$. Wychowywanie się w rodzinie, w której nie ma prawidłowych wzorców, a w ich miejsce dziecko obserwuje alkoholizm czy przestępczość rodziców powoduje trudności w założeniu własnej, poprawnie funkcjonującej rodziny, ponieważ dzieci zaczynają powielać zachowania swoich rodziców względem swoich dzieci ${ }^{42}$. Dzieci szczególnie mocno odczuwają na sobie także społeczną krytykę. W ich za-

39 A. Dymowska, M. Pięta, Dysfunkcjonalność systemu rodzinnego a przestępczość nieletnich, „The Polish Journal of Criminology” 2015, nr 1, s. 76 - 86.

40 K. Dymek-Balcerek, dz.cyt.

41 L. Pytka, Pedagogika resocjalizacyjna. Wybrane zagadnienia teoretyczne, diagnostyczne i metodyczne, Wydawnictwo Akademii Pedagogiki Specjalnej, Warszawa 2000, s. $92-93$.

42 Por. A. Szymanowska, Więzienie i co dalej, ŻAK, Warszawa 2003, s. 103. 
chowaniu najbliższe otoczenie poszukuje podobieństw z zachowaniem rodzica, by móc wyrażać komentarze typu: „,niedaleko pada jabłko od jabłoni”, czy ,jaki ojciec taki syn". Utrzymująca się negatywna opinia czy ocena może w konsekwencji prowadzić do międzypokoleniowego przekazu zachowań aspołecznych i powodować, że dziecko chcąc przerwać niekorzystne opinie na swój temat zaczyna reagować na nie agresją, a tym samym nieświadomie je potwierdza i umacnia ${ }^{43}$.

Jednym z obszarów, na które również należy zwrócić uwagę jest sytuacja szkolna dzieci osób pozbawionych wolności. Badania prowadzone przez E. Sapie-Drewniak pokazują, że dzieci te sprawiają liczne problemy wychowawcze: „Dziecko z rodziny zdezorganizowanej, często zaniedbane, emocjonalnie odrzucone lub też pozostawione samemu sobie najczęściej nie potrafi prawidłowo funkcjonować wśród rówieśników z rodzin nie przeżywających tego typu problemów. Różni się od nich z powodu nadmiernej agresji, bądź też apatyczności i bierności. Wśród badanej grupy na 96 dzieci aż 36 było izolowanych, odrzucanych przez klasę. Ponadto badane dzieci miały problemy w nauce. Konsekwencją trudności dydaktycznych badanych dzieci było zjawisko drugoroczności wśród nich. W badanej grupie 16 uczniów powtarzało klasę dwukrotnie. Trudności z przygotowaniem się do lekcji, lęk przed ośmieszeniem w klasie powodowały, iż 22 uczniów opuszczało bez usprawiedliwienia zajęcia lekcyjne." ${ }^{\prime 4}$.

Istotnym elementem, na który należy zwrócić uwagę w przypadku dzieci rodziców pozbawionych wolności jest niewydolność wychowawcza ich środowiska rodzinnego. Przestępczość jednego z rodziców stanowi zwykle jeden z czynników z nią skorelowanych, który w ,połączeniu” z takimi okolicznościami jak chociażby uzależnienia, zła sytuacja materialna, kłótnie i awantury prowadzi do trwałego zaniedbania dziecka i nie wywiązywania się rodziców z nałożonych na nich zadań. $\mathrm{W}$ rezultacie często obserwowanym zjawiskiem są ucieczki dziecka $\mathrm{z}$ domu ${ }^{45} \mathrm{czy}$ umieszczenie dziecka w placówce opiekuńczo-wychowawczej ${ }^{46}$.

\section{Zamiast zakończenia}

Izolacja więzienna negatywnie oddziałuje na sytuację całej rodziny, stając się przyczyną licznych trudności i nieporozumień. Konieczne jest zatem podejmowanie

43 Por. B. Hołyst, Wiktymologia, LexisNexis, Warszawa 2006, s. 1036.

${ }^{4}$ E. Sapia- Drewniak, Sytuacja szkolna dzieci osób karanych pozbawieniem wolności, „Przegląd Penitencjarny i Kryminologiczny” 1989, nr 17, s. 82-91.

45 Por. T. Sakowicz, dz. cyt., s. $103-104$.

46 A. Majchrowska-Kielak, Przyczyny odebrania dziecka rodzicom. Sytuacja materialna i elementy kontekstu rodzinnego, „Probacja” 2015, nr 4, s. 5 - 29. 
działań, mających na celu poprawę zaistniałej sytuacji, by jednak można było mówić o skuteczności tychże działań powinny mieć one miejsce od momentu osadzenia, przez cały okres kary, jak również po jej zakończeniu ${ }^{47}$. Co więcej winny być realizowane w różnej formie i przez różne podmioty. W odniesieniu do pierwszego postulatu wartościowym wydaje się wyjście poza system świadczeń pieniężnych i zorganizowanie dla rodzin więźniów wsparcia w postaci pomocy w opiece nad dziećmi oraz poradnictwa rodzinnego - jego celem powinno być przygotowanie rodziny do samodzielnego rozwiązywania problemów, budowania na nowo relacji rodzinnych oraz nauka właściwych sposobów komunikacji ${ }^{48}$. Wartym uwagi wydaje się być także przygotowanie oferty szkoleń dla wszystkich, którzy mają kontakt z rodziną i dziećmi osób pozbawionych wolności (pedagogów, nauczycieli) - dotyczyć powinny rozpoznawania i reagowania na zmiany, jakie na skutek izolacji rodzica mogą pojawić się w zachowaniu dziecka. Jeżeli chodzi z kolei o zaangażowanie różnych podmiotów w pomoc rodzinie, angażować się $\mathrm{w}$ nie winni nie tylko pracownicy socjalni czy asystenci rodziny, ale również funkcjonariusze Służby Więziennej. To na nich spoczywać powinien trud podejmowania działań sprzyjających utrzymaniu i poprawie relacji rodzinnych w czasie trwania kary. Obecnie funkcjonariusze Służby Więziennej opracowują liczne programy mające przygotować skazanych do pełnienia roli męża/ojca, brak jest jednak działań, które sprzyjałyby integracji rodziny w czasie odbywania przez osadzonego kary pozbawienia wolności, co w rezultacie powodować może, że skazany wyposażony w określone kompetencje nie ma możliwości ich wykorzystania w praktyce, ponieważ w trakcie jego pobytu w izolacji jego rodzina uległa rozpadowi i nie jest zainteresowana zmianą tejże sytuacji. Konieczne wydaje się zatem prowadzenie wobec skazanego i jego rodziny programów profilaktycznych, resocjalizacyjnych czy terapeutycznych, które umożliwiałyby odbudowę zubożałej sfery kontaktów, między innymi poprzez: wypracowywanie pozytywnych modeli relacji, wypracowywanie wspólnych - rodzinnych sposobów podejmowania decyzji i rozwiązywania problemów, niwelowanie negatywnych wzorców rodzicielskich oraz budowanie zaufania i zaangażowania, redukcję funkcjonującego w relacjach strachu, stresu oraz powstałych barier komunikacyjnych ${ }^{49}$.

47 A. Fidelus, Praca na rzecz rodziny doświadczającej problemów związanych z izolacja więzienna jednego z jej członków, w: Rodzina w pracy socjalnej-pomoc $w$ sytuacjach trudnych i kryzysowych, red. T. Biernat, K. Kuziak, J.A. Malinowski, AKAPIT, Toruń 2016, s. 339.

48 Por. A. Domżalska, Dzieci rodziców pozbawionych wolności, „Forum Pedagogiczne” 2011, nr 1, s. 222.

49 Por. E. Pindel, dz. cyt., s. 100. 
Przedstawiona pokrótce problematyka pokazuje jak poważnym zagrożeniem dla prawidłowego funkcjonowania rodziny jako systemu oraz jego pojedynczych członków jest przymusowa izolacja jednego z członków rodziny. W tym kontekście niezbędne jest podejmowanie działań, które będą w stanie zapobiegać tym negatywnym konsekwencjom lub niwelować je. By jednak było to możliwe konieczna jest integracja różnych służb i form pomocy, bowiem tylko ona jest w stanie zmienić sytuację rodzin, a zwłaszcza dzieci osób pozbawionych wolności.

\section{Renata Deka: Penalty of imprisonment - crisis in the life of the convicted and his family}

\section{Summary}

The penalty of imprisonment is one of the basic instruments of influencing the perpetrators of crimes. Although this punishment is a natural and fully justified consequence of a socially unacceptable act, it cannot be overlooked that its use also has negative consequences, not only for the functioning of the convicted person but also for the entire family system.

This article presents the imprisonment-related problems of the convicted and his family, with special focus on the situation of convicted people's children. The material also contains conclusions and recommendations regarding the topic in question.

Key words: convicted, penalty of imprisonment, crisis, family of prisoners, convicted people's children

\section{Bibliografia}

Allport G.W., Osobowość i religia, PAX, Warszawa 1988.

Barczykowska A., Sytuacja życiowa rodzin osób pozbawionych wolności, w: Rodzina i praca z perspektywy wyzwań i zagrożeń, red. Golińska L., Dudek B., Wydawnictwo Uniwersytetu Łódzkiego, Łódź 2008.

Caplan G., Principles of preventive psychiatry, Basic Book, New York 1964.

Chmielewska W., Psychologiczne aspekty izolacji, w: Zagadnienia penitencjarne. Skrypt dla stuchaczy szkoły podoficerskiej SW, red. Chmielewska H. i in., Kalisz 2004.

Ciosek M., Psychologia sadowa i penitencjarna, PWN, Warszawa 2001.

Cochra J.C., Mears D.P., Social isolation and inmate behavior: A conceptual framework for theorizing prison visitation and guiding and assessing 
Cox V.C., Paulus P.B., McCain G., Prison crowding research, „American Psychologist" 1984, nr 39.

Deka R., Zaangażowanie więźniów w praktyki religijne jako jedna z form zapobiegania negatywnym konsekwencjom izolacji więziennej, [w:] Badania i Rozwój Młodych Naukowców w Polsce. Nauki humanistyczne i społeczne, cz. III, red. J. Nyćkowiak, J. Leśny, Wyd. Młodzi Naukowcy, Poznań 2017.

Domżalska A., Dzieci rodziców pozbawionych wolności, „Forum Pedagogiczne” 2011, nr 1, s.222.

Dymek-Balcerek K., Dziecko w obliczu patologii społecznej dnia codziennego-rzeczywistość lat 90-tych, Wydawnictwo Politechniki Radomskiej, Radom 1999.

Dymowska A.,Pięta M., Dysfunkcjonalność systemu rodzinnego a przestępczość nieletnich, „The Polish Journal of Criminology” 2015, nr 1

Fidelus A., Praca na rzecz rodziny doświadczajacej problemów zwiąanych z izolacja więzienna jednego z jej członków, w:Rodzina w pracy socjalnej-pomoc w sytuacjach trudnych i kryzysowych, red. Biernat T., Kuziak K., Malinowski J.A., AKAPIT, Torun 2016.

Gerrig R.J., Zimbardo P.G. , Psychologia i życie, PWN, Warszawa 2006.

Giza J.S., Morasiewic W., Homoseksualizm w środowisku więźniów młodocianych, „Przegląd Penitencjarny” 1968, nr 4.

Goffman E., Charakterystyka instytucji totalnych, w: Elementy teorii socjologicznych. Materiały do dziejów współczesnej socjologii Zachodniej, red. W. Derczyński, A. Jasińska-Kania, J. Szacki, 1975.

Gorzelak P, Wpływ rodziny na sposób adaptacji młodocianych więźniów w areszcie śledczym na podstawie spotkań organizowanych przez administracje Á́ z rodzinami, w: Młodociani więźniowie. Problemy współczesnej rzeczywistości penitencjarnej, red. Lubicki L., Wydawnictwo ZK, Włocławek 2001.

Hagan J., The Next generation: Children of prisoners, „Journal of the Oklahoma Criminal Justice Research Consortium" 1996, nr 3.

Hołyst B., Wiktymologia, LexisNexis, Warszawa 2006.

Jaworska A., Leksykon resocjalizacji, Oficyna Wydawnicza Impuls, Kraków 2012. Kosewski M, Agresywni przestępcy, Wiedza Powszechna, Warszawa1977.

Lewandowski M., Pęknięcie ziemi, Czytelnik, Warszawa 1975.

Majchrowska-Kielak A., Przyczyny odebrania dziecka rodzicom. Sytuacja materialna i elementy kontekstu rodzinnego, „Probacja” 2015, nr 4.

Mazur J., Wpływ kontaktu z rodzina na funkcjonowanie osadzonego $w$ warunkach izolacji. Realizacja funkcji rodzinnych-próba opisu, w: Osobowość przestepcy a proces resocjalizacji, red. Świtka J., Kuć M., Niewiadomska I. (red.), Wydawnictwo KUL, Lublin 2004. 
Pindel E., Podtrzymywanie więzi rodzinnych $w$ warunkach izolacji, „Probacja” 2011, nr 1, s.92-99.

Płużek Z., Psychologia pastoralna, Inst. Teolog. Księży Misjonarzy, Kraków 1991. Poklek R., Instytucjonalne i psychospołeczne aspekty więzienia, Centralny Ośrodek Szkolenia Służby Więziennej, Kalisz 2010.

Przybyliński S., Podkultura więzienna - wielowymiarowość rzeczywistości penitencjarnej, Oficyna Wydawnicza Impuls, Kraków 2012.

Pytka L., Pedagogika resocjalizacyjna. Wybrane zagadnienia teoretyczne, diagnostyczne

Research, „Journal of Criminal Justice”2013, nr 41.

Rzepliński A., Rodziny więźniów dtugoterminowych, Ossolineum, Wrocław 1981.

Sakowicz T., Dysfunkcjonalność rodziny a resocjalizacja, Oficyna Wydawnicza Impuls, Kraków 2006.

Sapia- Drewniak E., Sytuacja szkolna dzieci osób karanych pozbawieniem wolności, „Przegląd Penitencjarny i Kryminologiczny” 1989, nr 17.

Siemaszko A., Granice tolerancji, PWN, Warszawa 1993.

Sikora J., Znaczenie barw w życiu człowieka $i$ w warunkach izolacji więziennej, „Przegląd penitencjarny i kryminologiczny” 1971, nr 1.

Szczepanik R., Miszewski K., Wpływ długoterminowego uwięzienia na rodziny więźniów — stan wiedzy i zaniedbane kierunki badań, „Profilaktyka Społeczna i Resocjalizacja" 2016, nr 30, s.53-95.

Szymanowska A., Więzienie i co dalej, ŻAK, Warszawa 2003.

Terelak J., Człowiek i stres, Wyd. UKSW, Warszawa 2007.

Travis J., McBrige E.C., Salomon A.L., Familie left behind: The hiddencosts of incarceration and reentry, Washington, 2003.

Wawrzyniak M., Chmielewska A., Uwięzienie a syndrom aleksytymii, „Psychologia Jakości Życia” 2002, nr 1, s.115-127.

Wawrzyniak M., Chmielewska-Hampel H., Izolacja więzienna jako sytuacja trudna a aleksytymia, „Psychologia jakości życia” 2009, tom 8, nr 2.

Żwyucka-Kozłowska E., Naznaczeni, odtraceni, wykluczeni... Kilka uwag o spotecznej sytuacji osób opuszczajacych zakłady karne, w: Meandry wykluczenia społecznego, red. Nowak J., Wyższa Szkoła Pedagogiczna TWP, Warszawa 2008.

http://agb.waw.pl/cms/index.php/zakad-karny/placowki/33-izolacja-wizienna [dostęp: 20.08.2017]

eWKratke - blog kobiet osadzonych w Areszcie śledczym Warszawa-Grochów, http://ewkratke.blog.pl/2014/09/01/tryptyk-jak-plynie-czas-w-wiezieniu/ [dostęp: 25.07.2017]http://fakty.interia.pl/tylko-u-nas/news-winy-rodzicow-nie-pietnuja-dzieci,nId,2211573 [dostęp: 23.07.2017] 